
\title{
IJBF MARKET REACTIONS TO AUDIT
COMMITTEE DIRECTOR'S GENDER: EVIDENCE FROM US-TRADED FOREIGN FIRMS
}

\author{
Hua-Wei Huang \\ National Cheng Kung University, Taiwan, ROC \\ Yun-Chia Yan \\ University of New Orleans, USA \\ James M. Fornaro \\ State University of New York-College at Old \\ Westbury, USA \\ Ahmed Elshahat \\ University of New Orleans, Bradley University, \\ USA
}

\begin{abstract}
This study investigates whether the appointment of a female to the audit committee of a foreign issuer in the US is positively associated with subsequent market price reaction. We hypothesize that female members on the audit committee can strengthen corporate governance by their conservative and ethical qualities. Accordingly, such appointments deliver a positive message to capital market participants. In order to observe the impact of audit committee gender diversity on foreign firms, we include all audit committee appointments for UStraded foreign firms from 2002 to 2009. We find that the appointment of female audit committee members has significant positive cumulative abnormal returns compared to the appointment of male audit committee members.
\end{abstract}

Keywords: Audit committee, Female director, Corporate governance, Market price reaction, US-traded foreign firms

JEL Classification: G14, M42, O16

\section{Introduction}

The primary purpose of this study is to investigate whether the appointment of a female to the audit committee of a foreign issuer in the US is positively associated with subsequent market price reaction. Research shows that female members on the audit committee can strengthen corporate governance by their 
conservative and ethical qualities. Accordingly, when a firm announces the appointment of a female to its audit committee, it delivers a positive message to capital market participants. In order to observe the impact of audit committee gender diversity on foreign firms, we include all audit committee appointments for U.S.-traded foreign firms from 2002 to 2009 in our sample.

Over the past two decades, foreign issuers have found the US capital markets to be an important gateway for capital-raising activities. However, the attractiveness and growth of other international stock exchanges (e.g., Hong Kong, Tokyo and London) represent significant challenges to the competitive position of the American markets. Indeed, the sluggish economic conditions in the country and the challenging global economic environment also present significant obstacles to the competitiveness of our capital markets. ${ }^{1}$ These conditions signal the need for the US to attract new listings by foreign firms while retaining the existing population of foreign listings.

In response to a series of financial scandals in the early 2000s, the SarbanesOxley Act (SOX) was signed into law in 2002 to restore investor confidence in the capital markets and financial reporting in general. The provisions of SOX encompass four major areas: business ethics, internal controls and procedures, governance and independence, and reporting and disclosures. Although particular sections of SOX focus on strengthening the corporate governance of public firms, evidence suggests that these strict requirements and onerous compliance costs present barriers to foreign firms since SOX does not provide them with a general exemption from its provisions. For example, Hostak, Karaoglu, Lys and Yang (2009) note that foreign firms, which voluntarily deregistered from exchanges, had weaker corporate governance and experienced, a significantly negative stock market reaction when SOX was passed. These firms also suffered a significant price decline when they announced their intention to deregister. Given this environment, Balakrishnan (2007) suggests that the future challenge for the SEC is to balance two competing goals which include: (1) protecting investors by setting sound standards of corporate governance, and (2) enhancing the attractiveness of the capital markets, particularly with respect to foreign issuers.

SOX includes several provisions that focus on strengthening the role of the audit committee as a critical monitor over the financial reporting process. In particular, Section 301 (SOX 301) states that the audit committee "shall be directly responsible for the appointment, compensation, and oversight" of the auditor. Under SOX 301, audit committee members are expected to be concerned about their personal reputations and ensure that the external auditors have fulfilled their responsibilities. Moreover, audit committee members are required to be independent and are prohibited from accepting compensatory or advisory fees from the firm. Eaddy et al. (2003) indicate that the audit committee requirements raise significant problems for most foreign issuers because they deal

\footnotetext{
${ }^{1}$ As of 2003, over 1,300 foreign companies from almost 60 countries filed disclosure reports with the SEC, compared with approximately 400 companies from less than 30 countries in 1990 (Eaddy, Faciszewski, Fitz \& Van Lowe, 2003). As of 2008, foreign listings had declined to 1,024 companies from 50 countries (Deloitte, 2010).
} 
with technical structures, relationships and processes rather than with ultimate results, as do most of the disclosure requirements. Again, given the lack of a general exemption for public foreign issuers, it is important to understand how the characteristics of audit committee members affect foreign firms.

Prior research (e.g., McMullen \& Raghunandan, 1996; Klein, 2002; Bedard, Chtorou \& Courteau, 2004; DeFond, Hann \& Hu, 2005) has explored the following characteristics of audit committee members: independence, meeting frequency, size, and financial expertise. Moreover, specific research concerning the effect of gender diversity of audit committee members has recently emerged. Ittonen, Miettinen and Vahamaa (2009) find evidence that firms with female representation on the audit committee reduces the inherent risk of misstatements. Their results have implications for external auditing since they also find that gender diversity is associated with lower audit fees.

Huse and Solberg (2006) find that female directors are better prepared for board meetings than male directors which results in improved board behaviour and effectiveness. These benefits should also be realized by audit committees with female membership.

Research on ethics finds that women are less likely to engage in unethical behaviour in the workplace to obtain financial rewards (Bernardi \& Arnold, 1997; Betz, O'Connell \& Shepard, 1989). Ruegger and King (1992) find that females are more ethical than males in their perceptions of ethical conduct in business situations. Moreover, related studies (e.g., Krishnan \& Parsons, 2008) find that earnings quality is positively associated with gender diversity in senior management, that females are more risk averse than men, and are less likely to engage in unethical behaviour in the workplace.

We find that the appointment of female audit committee members in U.S.-traded foreign firms has significantly positive cumulative abnormal market returns compared to the appointment of male audit committee members. Our findings contribute to the extant literature in several ways. First, the results confirm that share prices react favourably to the appointment of females to the audit committee. This reinforces the belief that gender diversity enhances the perceptions of market participants with respect to the audit committee's independence and the overall performance of the governance function. Second, this study has implications for global investors and other users of financial information who are contemplating future investments in the US capital markets. If the SEC's major goal is to improve the quality of corporate financial reporting, it should encourage gender diversity on audit committees.

Finally, this study contributes to the emerging literature that examines the effects of audit committee gender diversity. We provide additional evidence from the market participants' perspective that the appointment of female audit committee members contributes to shareholder value by improving the reliability of financial reporting through enhanced monitoring.

The remaining sections of this paper are organized as follows. Section 2 outlines the related literature and hypotheses. Section 3 provides an explanation of the research method and data. In section 4, is provided the empirical tests and explanations of the results are presented. Section 5 is the conclusion. 
International Journal of Banking and Finance, Vol. 8, Iss. 1 [2011], Art. 4

\section{Related Literature and Hypothesis Development}

\subsection{Gender Research in Corporate Governance}

Traditional gender studies in the accounting literature have focused on the dissatisfaction of women in the workplace and the lack of high-level female directors $^{2}$ (e.g., Pillsbury, Capozzoli and Ciampa, 1989; Neidermeyer, Tuten and Neidermeyer, 2003). Behavioural studies in business have shown that women in the accounting profession are generally more ethical than men when performing accounting tasks. For example, Schaefer and Welker (1994) indicate that CPAs disciplined for work-related ethics violations are more likely to be males who practice in small firms. Bernardi and Arnold (1997) find that female managers are at a significantly higher average level of moral development than male managers in the Big Six accounting firms. Cohen, Pant and Sharp (1998) indicate that women have consistently different ethical evaluations, intentions and orientation than men. More specifically, women consider questionable actions to be less ethical than men, and indicate that they would be less likely to engage in certain actions than men. Neidermeyer et al. (2003) suggest that women believe that the practice of low-balling audit fees is less acceptable to women than to men, and women also agree significantly more often that low-balling is a violation of the "independence in appearance" clause of the AICPA Code of Professional Conduct. ${ }^{3}$ Chung and Monroe (2001) find significant gender differences with respect to information processing abilities and that females exercise more accurate audit judgment and decision-making abilities than males when faced with complex accounting decision tasks.

Due to these unique characteristics of women, researchers have recently begun to investigate how gender diversity influences the effectiveness and efficiency of corporate governance, particularly with respect to the board of directors and audit committees. For example, Carter, D'Souza, Simkins and Simpson (2008) indicate that gender diversity has a positive effect on financial performance primarily through the audit function of the board of directors. Ittonen et al. (2009) suggest that female representation on audit committees may decrease audit fees by affecting the auditor's assessment of the integrity of the financial reporting process, as well as by reducing the inherent risk of misstatements. Gul, Srinidhi and Tsui (2008) find that boards with female directors are more likely to demand higher monitoring in the form of more audit effort. Levi, Li and Zhang (2008) document that the bid premium over the

\footnotetext{
${ }^{2}$ Although a substantial number of women have entered the public accounting profession, only $3.7 \%$ of the partners in the Big Eight accounting firms are women (Pillsbury et al., 1989).

${ }^{3}$ Two parts of the Code cover Principles and Rules. The Principles are goal-oriented and represent guidelines that address members' responsibilities, public interest, integrity, objectivity and independence, due care, and the scope and nature of services to the public, clients and fellow practitioners. The Rules are more detailed enforceable applications that support the Principles.
} 
preannouncement target share price is statistically and economically smaller when there is a larger proportion of women on the target company's board, provided that the female directors are independent appointees. Abbott, Parker and Presley (2009) study the relationship between board diversity and financial restatements and find that a female board presence is indicative of a more control-conscious CEO and a more vigilant board of directors. In summary, extant gender studies document the positive influence of female representation on the corporate governance function.

\subsection{Market Reaction to the Appointment of Audit Committee Members}

Investors respond to important announcements and events that are believed to impact a firm's value at a point in time. The appointment of a new audit committee member can be viewed as critical information to market participants. Previous studies document a significant increase in the market's reaction to earnings reports subsequent to the formation of the audit committee (Wild, 1996). Davidson, Xie and Xu (2004) find significantly positive stock price reaction when newly appointed members of audit committees have financial expertise. Further, DeFond et al. (2005) document a positive market reaction to the appointment of accounting experts assigned to audit committees.

These studies demonstrate the existence of information content in the capital markets for audit committee related announcements. Given this discussion and the positive influence of female representation on corporate governance, we expect that the appointment of a female to the audit committee provides significant information content regarding:

(1) enhanced oversight over the firm's financial reporting process,

(2) more effective supervision over the external auditor, and

(3) expected improvements in the quality of the firm's financial reporting to market participants.

We further hypothesize that this signal simultaneously induces favourable market price reactions as follows:

Hypothesis 1a: Market reaction in response to the appointment of a female audit committee member is positive.

Hypothesis $1 \mathrm{~b}$ : Market reaction in response to the appointment of a male audit committee member is neutral/negative.

Hypothesis 2a: Market reaction is positively associated with the number of female audit committee members appointed.

Hypothesis 2b: Market reaction is neutrally/negatively associated with the number of male audit committee members appointed. 
International Journal of Banking and Finance, Vol. 8, Iss. 1 [2011], Art. 4

\section{Research Method, Data and Variables}

\subsection{Model Specification}

To examine our hypotheses, the following OLS regression models are employed (e.g. Chen \& Church, 1996; DeFond et al. 2005; Choi, Kim, Liu \& Simunic, 2008):

$$
\begin{aligned}
C A R= & \alpha+\beta_{1} C H P R I C E+\beta_{2} L n M V E+\beta_{3} L E V E R A G E+ \\
& \beta_{4} L n R E G I M E+\beta_{5} L n G D P+\beta_{6} \text { FDI }+\beta_{7} L n E Q U I T Y \\
& +\beta_{8} D I S C L+\beta_{9} T E C H+\beta_{10} L I S T A N N+ \\
& \beta_{11} \text { FEMALE }+\varepsilon
\end{aligned}
$$

Where:

CAR = Cumulative abnormal market returns;

CHPRICE $=$ Changes in stock price prior to the issuance of the auditor's report;

LnMVE = Natural log of the market value of equity;

LEVERAGE = Total debt divided by total assets;

LnREGIME $=$ The strictness of a country's legal regime, measured by the natural log of Wingate's 1997 litigation index for each country;

LnGDP = Natural log of gross domestic product (GDP) per capita (in thousands of US dollars);

FDI $\quad=$ Foreign direct investment scaled by GDP;

LnEQUITY = The importance of each country's equity market, measured by the natural log of extent to which each country's firms rely on equity financing (the data are extracted from Choi and Wong, 2005);

DISCL $\quad$ A country's disclosure level measured by the Center for International Financial Analysis and Research (CIFAR) index;

TECH = 1 if a technology firm (defined as $\mathrm{SIC}=3570-3579,3670$ 3679 , and 7370-7379), else 0;

LISTANN $=1$ if the firm is traded on AMEX, NASDAQ or NYSE, else 0 ; and

FEMALE $\quad=1$ if a female audit committee member is appointed, else 0 .

$$
\begin{aligned}
C A R= & \alpha+\omega_{1} \text { CHPRICE }+\omega_{2} \text { LnMVE }+\omega_{3} L E V E R A G E+ \\
& \omega_{4} \text { LnREGIME }+\omega_{5} L n G D P+\omega_{6} \text { FDI }+\omega_{7} \text { LnEQUITY }+ \\
& \omega_{8} \text { DISCL }+\omega_{9} \text { TECH }+\omega_{10} L I S T A N N+\omega_{11} \text { FSIZE }+ \\
& \omega_{12} \text { MSIZE }+\varepsilon
\end{aligned}
$$


Where:

FSIZE = Number of female audit committee members appointed;

MSIZE = Number of male audit committee members appointed; and the other variables are the same as in model (1).

Our main tests consist of a traditional event study that examines: (1) three-day $(-1$ to +1$)$; (2) seven-day $(-3$ to +3$)$, and (3) eleven-day $(-5$ to +5$)$ CAR around the appointment disclosure dates of the new audit committee members. In the OLS regression models, CAR is regressed on variables of interest representing gender diversity, such as FEMALE, FSIZE, and MSIZE. We control for the potential effects of the size of the company and total market environment by using the following three variables: CHPRICE, LnMVE, and LEVERAGE as in previous studies (Chen \& Church, 1996; DeFond et al., 2005). Country-specific litigation and governance variables, including LnREGIME, LnGDP, FDI, LnEQUITY and DISCL, are controlled as in Choi et al. (2008). As in Choi et al. (2008), each country has one litigation index, GDP, FDI, equity index, and disclosure level index. Therefore, US-traded foreign firms from the same country will be assigned the same governance indices. The GDP and FDI are different by years, but the litigation index, equity index, and disclosure level index are the same across the sample years due to data availability.

\subsection{Sample Selection}

Panel A of Table 1 provides a summary of the sample selection process. The initial sample of 476 audit committee appointments (from 2002 to 2009) by foreign firms were obtained from the AuditAnalytics database. To clearly identify that the CAR is driven by male or female appointments separately, we excluded 182 companies that appointed both female and male members on the same day. After matching with the Compustat and CRSP databases, the missing financial data reduces the available observations to 107 for our regression analysis. There are no delisted firms in our final sample. Panel B shows that the selected firms are distributed among 14 countries/economic entities. The highest representation is by Canadian firms (56) followed by firms from the United Kingdom (20) and China (12).

\section{Results}

\subsection{Descriptive Statistics}

Table 2 provides descriptive statistics on the full sample tested in this study. ${ }^{4} \mathrm{We}$ use Eventus to calculate the CAR for all of our 107 sample firms. The mean and median CAR in all three event windows are negative. Sixty-three per cent of our

\footnotetext{
${ }^{4}$ Extreme observations are winsorized at $5 \%$ and $95 \%$ to reduce the potential influences of outliers.
} 
International Journal of Banking and Finance, Vol. 8, Iss. 1 [2011], Art. 4

selected firms were traded on AMEX, NASDAQ or NYSE (LISTANN). Ten per cent of our sample firms reported the appointment of a female audit committee member (FEMALE).

Table 1: Sample Selection Process and Composition

\section{Panel A: Sample selection process}

Number of new appointments of Audit Committee members:

January 1, 2002 - December 31, 2009

Less: companies that appointed both female and male members on the same day* -182

Sample used for restatement analysis

Less: Companies missing Compustat or CRSP financial data

Sample used for regression analysis

$\underline{107}$

* Our sample consists of companies that appointed only either (1) female or (2) male members. Thus we exclude companies that appointed both female and male members on the same day from our analysis.

\begin{tabular}{lr} 
Panel B: Sample composition by country/economic entity Country & $\underline{\mathbf{N}}$ \\
Argentina & 2 \\
Australia & 2 \\
Canada & 56 \\
China & 12 \\
Costa Rica & 2 \\
France & 3 \\
Hong Kong & 2 \\
Ireland & 1 \\
Netherlands & 1 \\
Netherlands Antilles & 2 \\
Panama & 1 \\
Russia & 1 \\
Singapore & 2 \\
United Kingdom & 20 \\
Total & $\underline{107}$ \\
\hline
\end{tabular}

Also, the mean value of MSIZE (1.02) is higher than that of FSIZE (0.13). The mean (74.38) and median (73.00) DISCL of foreign firms are lower than US firms (86), as expected. The mean (1.80) and median (1.65) LnREGIME of our sample firms both fall within a normal range. ${ }^{5}$

${ }^{5}$ Choi et al., 2008 suggest that the value of LnREGIME in a country with a strong (weak) legal regime is 2.40 (1.50). 
Huang et al.: Market Reaction to Audit Committee Gender

Market Reactions to Audit Committee Director's Gender: Evidence from US-Traded Foreign Firms: 59-75

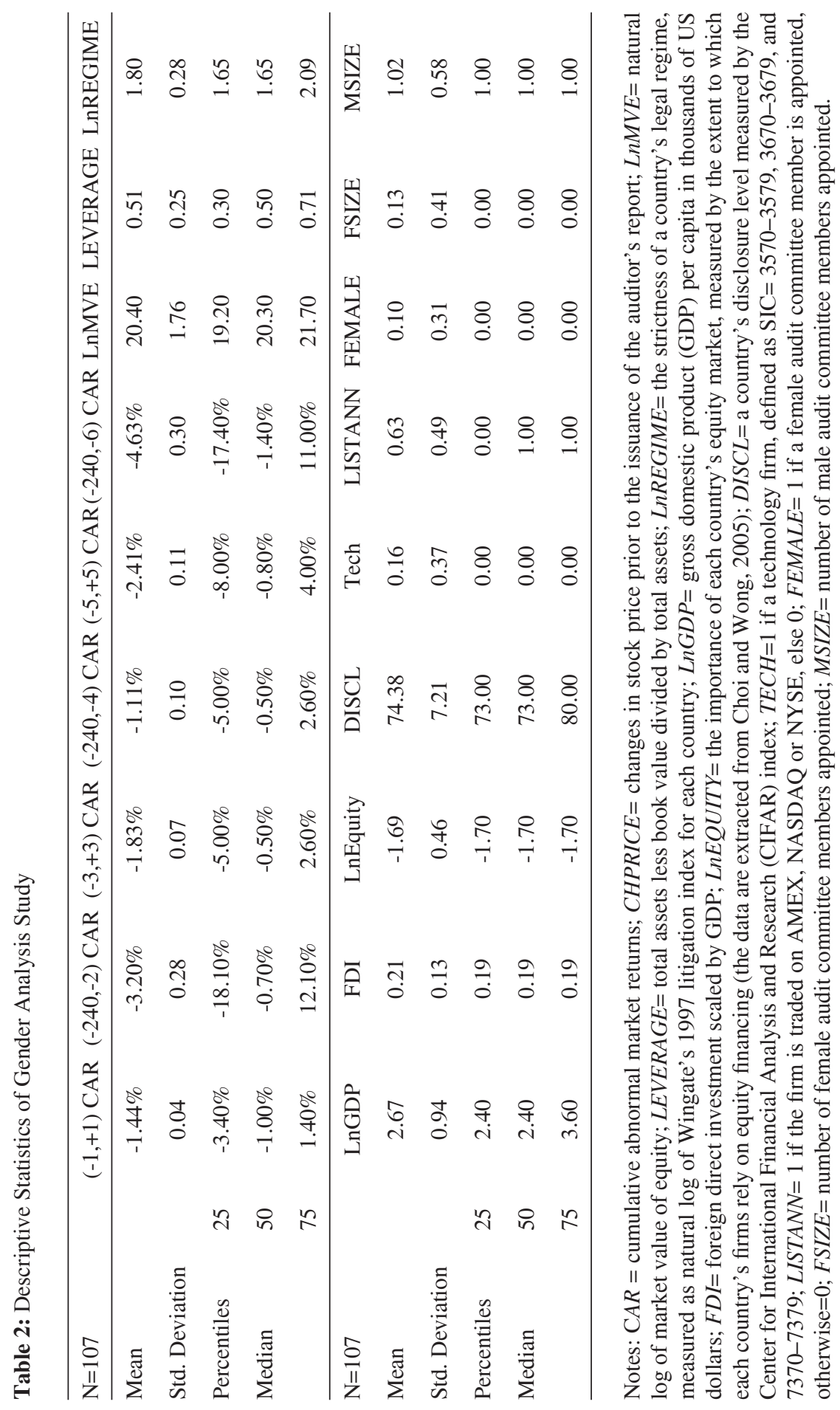


International Journal of Banking and Finance, Vol. 8, Iss. 1 [2011], Art. 4

Table 3: CAR Analysis on Gender Difference of Audit Committee Appoinments

\begin{tabular}{lccc}
\hline & CAR $(-1,+1)$ & CAR $(-3,+3)$ & CAR $(-5,+5)$ \\
\hline Female mean (N=11) & $-1.55 \%$ & $1.42 \%$ & $1.92 \%$ \\
Female median (N=11) & $-2.30 \%$ & $2.60 \%$ & $3.70 \%$ \\
Male mean (N=96) & $-1.43 \%$ & $-2.21 \%$ & $-2.91 \%$ \\
Male median (N=96) & $-0.95 \%$ & $-1.05 \%$ & $-1.55 \%$ \\
& & & \\
Independent t-test & & & \\
$\quad$ t value & 0.204 & 0.382 & 0.731 \\
$\quad$ p-value & 0.937 & $\mathbf{0 . 0 8 3}$ & 0.171 \\
& & & \\
Non-parametric test & & & \\
Mann-Whitney U & 509 & 357 & 380 \\
Wilcoxon W & 575 & 5013 & 5036 \\
$Z$ & -0.20 & -1.76 & -1.52 \\
p-value & 0.841 & $\mathbf{0 . 0 7 8}$ & 0.129 \\
\hline
\end{tabular}

Notes: Where $C A R=$ cumulative abnormal market returns.

Table 3 presents the CAR analysis for both male and female groups. The mean and median of CAR in event windows $(-3,+3)$ and $(-5,+5)$ are positive for the appointment of female audit committee members. Conversely, the mean and median of CAR are negative in all three event windows for the appointment of male audit committee members.

The difference in CAR between male and female groups is significant $(\mathrm{p}<0.10$, two-tailed) in window $(-3,+3)$. Accordingly, the empirical results provide some evidence that the market reacted positively (negatively) to the appointment of female (male) committee members. Overall, however, the univariate tests provide weak evidence to support our hypotheses.

Table 4 shows the correlation matrix of our variables and reports significant results in window $(-3,+3)$. Both FEMALE and FSIZE are positively correlated with CAR and significant at the conventional level $(\mathrm{p}<.10$, twotailed). In window $(-5,+5)$, FSIZE is also positively correlated with CAR and significant (at $\mathrm{p}<.10$, two-tailed). For male appointments, MSIZE is negatively correlated with CAR $(-3,+3)$ and significant at the conventional level $(\mathrm{p}<.05$, two-tailed). Accordingly, the correlation analysis provides consistent evidence to support our major hypotheses 
Huang et al.: Market Reaction to Audit Committee Gender

Market Reactions to Audit Committee Director's Gender: Evidence from US-Traded Foreign Firms: 59-75

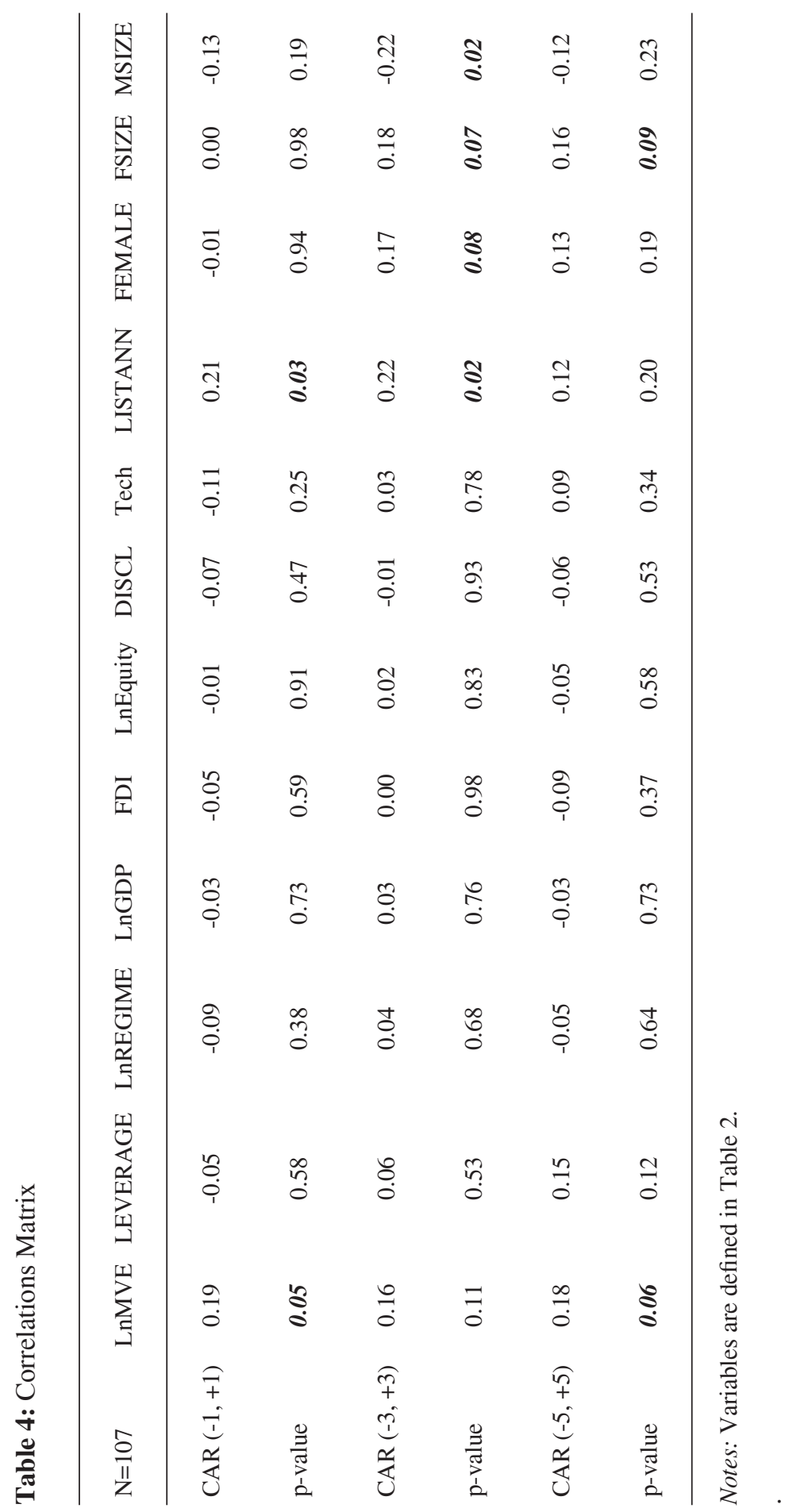




\subsection{OLS Regression Results}

Table 5 reports the OLS regression results for the primary tests. ${ }^{6}$ Several control variables are significant in window $(-5,+5)$, including CHPRICE, FDI, $D I S C L$, and TECH. As expected, CAR is positively associated with the firms' prior market returns (CHPRICE). Technology firms with higher industrial risks experience greater market reactions after the appointments of female directors. This is perhaps due to the positive influences of female representation on the financial reporting process and the quality of financial reporting, particularly in firms exposed to higher risks. The coefficients of FDI and DISCL are both negatively significant in event window CAR $(-5,+5)$, which suggests that a country's foreign direct investment (scaled by total GDP) and disclosure level reduce the impact of the appointment of female audit committee members on the market price of foreign firms. A higher disclosure level (DISCL) is found to reduce the volatility of market reactions to the announcements of female appointments. The results of our variables of interest show that the appointment of female audit committee members has information content to the stock market in two event windows after controlling for the effects of cross-country variables. The coefficient of FEMALE is positive and significant $(+0.050, \mathrm{p}<.05$, twotailed) in event window CAR $(-3,+3)$ and $(+0.077, \mathrm{p}<.05$, two-tailed $)$ in event window CAR $(-5,+5)$.

These findings support our major hypotheses that the appointment of female audit committee members in U.S.-traded foreign firms has significant positive cumulative abnormal market returns compared to the appointment of male audit committee members. The coefficient of FSIZE is also positive and significant $(+0.070, \mathrm{p}<.05$, two-tailed $)$ in event window CAR $(-5,+5)$. The evidence shows that the greater the number of female audit committee members appointed, the greater the positive market return incurred. Conversely, the coefficients for MSIZE are negative and significant or insignificant in all event windows. This indicates that the number of male audit committee members appointed has a negative or no significant impact on the company's market price. This empirical evidence consistently supports our major hypotheses.

\subsection{Additional Analysis: Gender Diversity and Restatements}

If the presence of female audit committee members enhances audit committee effectiveness, it is reasonable to expect that such firms would experience fewer financial restatements subsequent to the appointment of female audit committee members. We investigated the association between audit committee gender diversity and financial restatements for the 294 firms indicated in Panel A of Table 1 by dividing our sample firms into: (1) female audit committee member appointment group ( $\mathrm{N}=23)$, and (2) male audit committee member appointment group ( $\mathrm{N}=271)$. We found that only 1 of the 23 foreign firms $(4.3 \%)$ restated their financial statements in the year subsequent to the appointment of female audit committee members.

${ }^{6}$ Multicollinearity should not be an issue since all VIFs are less than 2.0. 
Huang et al.: Market Reaction to Audit Committee Gender

Market Reactions to Audit Committee Director's Gender: Evidence from US-Traded Foreign Firms: 59-75

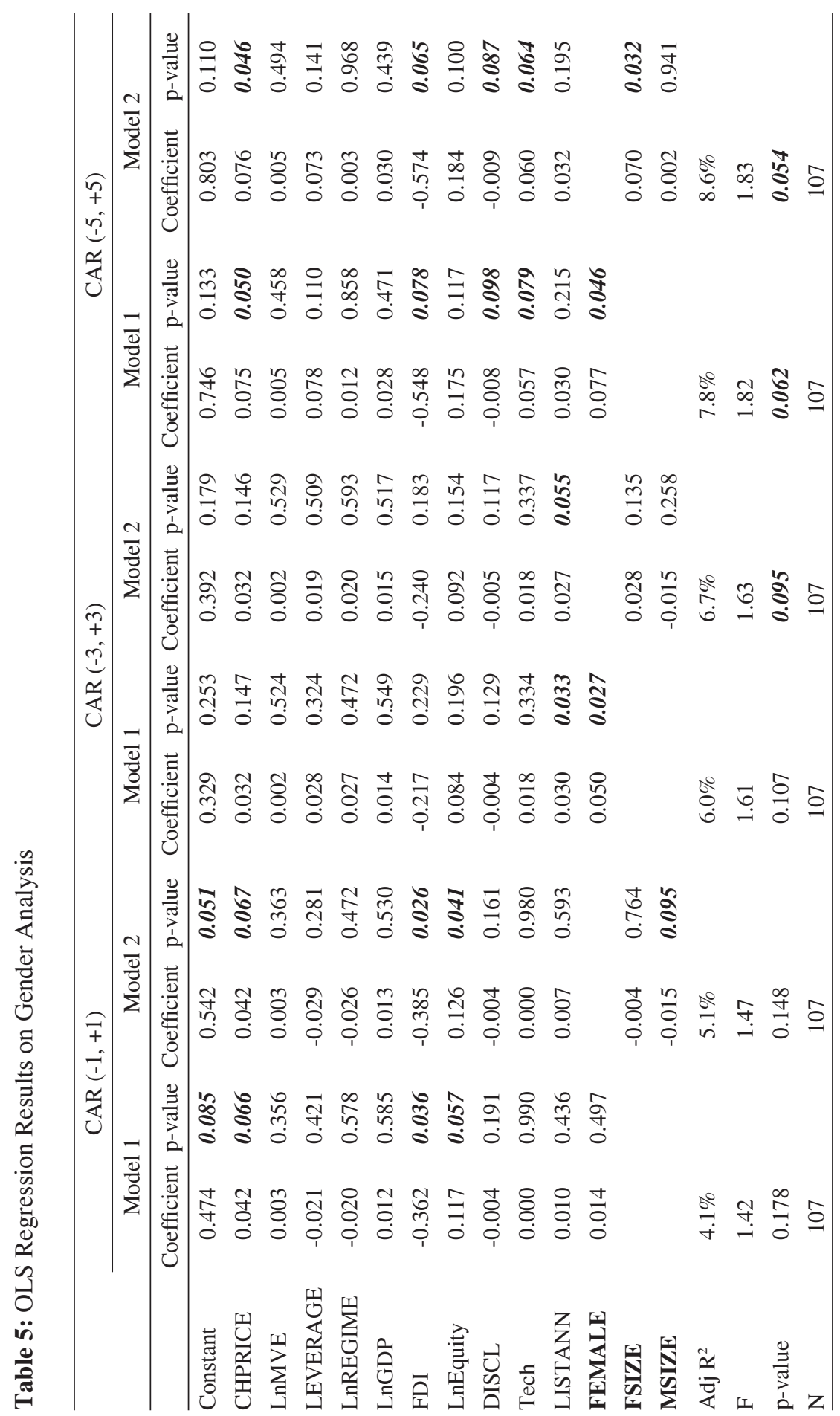


However, 23 of the 271 U.S.-traded foreign firms (8.4\%) restated their financial statements in the year subsequent to the appointment of male audit committee members. Accordingly, the percentage of restatements in the female group is significantly lower than that of the male group.

\subsection{Sensitivity Analysis}

The market reaction of financial firms may be different from other industries due to their unique characteristics. To control for this potential effect, an additional dummy control variable, FINANCE (finance firms, defined as SIC $=6000$ 6999), were included in the two OLS regression models. The results show that FINANCE is insignificant. The results of gender variables remain consistent with the results presented in Table 5.

We also designed a 1 by 1 matched sample based on the firms' SIC code as well as size and re-tested our mean and median differences of CAR between female and male groups in Table 3. The difference in CAR between the male and the female groups is consistently significant $(\mathrm{p}<.05$, two-tailed) in window $(-3$, $+3)$ and $(\mathrm{p}<.10$, two-tailed) in window $(-5,+5)$.

\section{Conclusion}

Researchers have recently begun to examine the important impact of gender diversity on audit committee effectiveness (two recent studies are Huse \& Solberg, 2006; Ittonen et al. 2009). This is particularly important given the enhanced role of the audit committee function under SOX. Also, the increased importance of foreign issuers to the American capital markets and concerns over competition from other exchanges (Balakrishnan, 2007) suggests that it is extremely important to understand how the characteristics of audit committees affect the quality of financial reporting of foreign firms.

In this study, we investigated the relationship between the appointment of female and male audit committee members and related market-price reaction for foreign firms. We found that the appointment of female audit committee members has significant positive cumulative abnormal returns compared to the appointment of male audit committee members.

Furthermore, the greater the number of female audit committee members appointed, the greater the positive market returns incurred. Our evidence reinforces the belief that gender diversity increases investors' confidence in a firm's audit committee and its ability to provide effective oversight over the financial reporting process as well as the external audit. These results have implications for global investors who seek to invest in the U.S. capital markets. These findings also suggest that, if the SEC's major goal is to improve the quality of corporate financial reporting, it should further stress the importance of female presence on the audit committee. 


\subsection{Limitations and Avenues for Future Research}

The following limitations apply to this paper. First, this study focused on the audit committee gender diversity of foreign firms traded in the US. The limited sample unavoidably reduced the power of the models and the significance of our variables. Second, we only examined the market reactions in three event windows following the appointment of a female audit committee member. The three event windows may not fully reflect the overall impact of this type of event. Future studies can explore whether audit committee gender diversity affects the firm's corporate governance by facilitating better earnings quality for US-traded foreign firms.

Author information: Hua-Wei Huang and James M. Fornaro are associate professors; Yun-Chia Yan and Ahmed Elshahat are assistant professors in their respective universities. Their e-mails are: hwawei7@yahoo.com.tw; yunchiayan@gmail.com; fornaroj@oldwestbury.edu; and aelshahat@ bradley. edu.

\section{References}

Abbott, L., Parker, S. \& Presley, T. (2009). Female board presence and the likelihood of financial restatement. American Accounting Association Annual Meeting.http://aaahq.org/AM2009/abstract.cfm ?submission ID= 3177.

Balakrishnan, J. (2007). Sarbanes-Oxley and foreign issuers: New developments. Asialaw, October: 1-9.

Bedard, J., Chtorou, S. M. \& Courteau, L. (2004). The effect of audit committee expertise, independence, and activity on aggressive earnings management. Auditing: A Journal of Practice and Theory, 23(2), 13-35.

Bernardi, R. A. \& Arnold, D. F. (1997). An examination of moral development within public accounting by gender, staff level, and firm. Contemporary Accounting Research, 14(4), 653-668.

Betz, M., O'Connell, L. \& Shepard, J. M. (1989). Gender differences in proclivity for unethical behavior. Journal of Business Ethics, 8(5), 321-324.

Carter, D., D’Souza, F., Simkins, B. \& Simpson, G. (2008). The diversity of corporate board committees and financial performance. Working Paper. Available at SSRN: http://ssrn.com/abstract=1106698.

Chen, K. C. W. \& Church, B. K. (1996). Going concern opinions and the market's reaction to bankruptcy filings. The Accounting Review, 71(1), 117-129.

Choi, J. \& Wong, T. (2005). Auditors' governance functions and legal environments: An international investigation. CIG Working Paper Series. Center for Institutions and Governance: Chinese University of Hong Kong. 
International Journal of Banking and Finance, Vol. 8, Iss. 1 [2011], Art. 4

Choi, J., Kim, J., Liu, X. \& Simunic, D. (2008). Audit pricing, legal liability regimes, and Big 4 premiums: Theory and cross-country evidence. Contemporary Accounting Research, 25(1), 55-99.

Cohen, J., Pant, L. \& Sharp, D. (1998). The effect of gender and academic discipline diversity on the ethical evaluations, ethical intentions and ethical orientation of potential public accounting recruits. Accounting Horizons, 12(3), 250-271.

Chung, J. \& Monroe, G. (2001). A research note on the effects of gender and task complexity on an audit judgment. Behavioral Research in Accounting, $13,111-125$.

Davidson, W., Xie, B. \& Xu, W. (2004). Market reaction to voluntary announcements of audit committee appointments: The effect of financial expertise. Journal of Accounting and Public Policy, 23(4), 279-293.

DeFond, M., Hann, R. N. \& Hu, X. (2005). Does the market value financial expertise on audit committees of boards of directors? Journal of Accounting Research. 43(2), 153-193.

Deloitte Touche Tohmatsu. (2010). Statistical database relevant to international financial reporting. IAS Plus. Available at: http://www.iasplus.com/stats/ stats.htm.

Eaddy, W. R., Faciszewski, S., Fitz, J.D. \& VanLowe, R.S. (2003). SarbanesOxley one year later: The impact on foreign issuers. Association of Corporate Counsel Annual Meeting.

Gul, F. A., Srinidhi, B. \& Tsui, J. (2008). Board diversity and the demand for higher audit effort. Working Paper. Available at: http://ssrn.com/ abstract $=1359450$.

Hostak, P., Karaoglu, E., Lys, T. \& Yang, Y. G. (2009). An examination of the impact of the Sarbanes-Oxley Act on the attractiveness of U.S. capital markets for foreign firms. Working Paper Series. Available at: http:// papers.ssrn.com/sol3/papers.cfm?abstract_id=956020.

Huse, M. \& Solberg, A. G. (2006). Gender-related boardroom dynamics: How Scandinavian women make and can make contributions on corporate boards. Women in Management Review, 21(2), 113-130.

Ittonen, K., Miettinen, J. \& Vähämaa, S. (2009). Does female representation in audit committees affect audit fees? Working Paper Series. Available at: http://papers.ssrn.com/sol3/papers.cfm?abstract_id=1314243.

Klein, A. (2002). Audit committee, board of director characteristics, and earnings management. Journal of Accounting \& Economics, 33(3), 375-400.

Krishnan, G. V. \& Parsons, L. M. (2008). Getting to the bottom line: An exploration of gender and earnings quality. Journal of Business Ethics, 78, 65-76.

Levi, M. D., Li, K. \& Zhang, F. (2008). Mergers and acquisitions: The role of gender. Working Paper. Available at SSRN: http://ssrn.com/ abstract $=1123735$.

McMullen, D. A. \& Raghunandan, K. (1996). Enhancing audit committee effectiveness. Journal of Accountancy, 182 (2), 79-81. 
Neidermeyer, P. E., Tuten, T. L. \& Neidermeyer, A. A. (2003). Gender differences in auditors' attitudes towards lowballing: Implications for future practice. Women in Management Review, 18(8), 406-413.

Pillsbury, C. M., Capozzoli, L. \& Ciampa, A. (1989). A synthesis of research studies regarding the upward mobility of women in public accounting. Accounting Horizons, 3(1), 63-71.

Ruegger, D. \& King, E. W. (1992). A study of the effect of age and gender upon student business ethics. Journal of Business Ethics, 11(3), 179-186.

Schaefer, J. \& Welker, R. (1994). Distinguishing characteristics of certified public accountants disciplined for unprofessional behavior. Journal of Accounting and Public Policy, 13(2), 97-119.

Wild, J. (1996). The audit committee and earnings quality. Journal of Accounting, Auditing \& Finance, 11(2), 247-276.

Wingate, M. (1997). An examination of cultural influence on audit environment. Research in Accounting Regulation, 11(Supplement), 129-48. 